\title{
Noninvasive molecular and morphological evidences for an undiscovered population of snow vole in Southern Spain
}

\author{
SAMER ALASAAD ${ }^{1,3}$, MICHAEL J. JOWERS $^{1}$, JOSÉ A. GARRIDO-GARCÍA ${ }^{1}$, \\ PETER WANDELER ${ }^{2}$, JOERNS FICKEL ${ }^{4}$, ANTONIO SÁNCHEZ ${ }^{3}$, \& RAMÓN C. SORIGUER ${ }^{1}$ \\ ${ }^{1}$ Estación Biológica de Doñana, Consejo Superior de Investigaciones Cientificas (CSIC), Avda. Américo Vespucio s/n 41092, \\ Seville, Spain, ${ }^{2}$ Institute of Evolutionary Biology and Environmental Studies (IEU), University of Zürich, Winterthurerstrasse \\ 190, 8057, Zürich, Switzerland, ${ }^{3}$ Departamento de Biología Experimental, Universidad de Jaén, Campus Las Lagunillas, s/n, \\ E-23071 Faén, Spain, and ${ }^{4}$ Research group Evolutionary Genetics, Leibniz-Institute for Zoo and Wildife Research, \\ Alfred-Kowalke-Street 17, D-10315 Berlin, Germany
}

\begin{abstract}
Capturing wild animals can be time consuming and difficult or even impractical. Noninvasive sampling is potentially a cost-effective and efficient means to monitor wild animals, thereby avoiding the need of capture and disturb species in the wild. On the basis of the morphological and genetic analyses of owl pellet contents, a so far undetected European snow vole (Chionomys nivalis) population was discovered in the Sierra Segura mountain range (Southern Spain). The mtDNA sequence from the newly discovered haplotype was compared with sequences from vole populations of the Sierra Nevada and Sierra Peñalara mountain ranges (Spain) and from Churwalden (Switzerland). The nine recovered haplotypes clustered in four distinct lineages according to their geographical origin. The vole sequence from the Sierra Segura owl pellet belonged to a new haplotype, constituting a new lineage. The evolutionary divergence between sequences from the Sierra Segura and other Spanish populations was higher than that among other Spanish haplotypes. The new snow vole haplotype from this new locality duplicates the number of occurrence sites of this critically endangered species in Southern Spain, which is of great interest for further conservation and management plans of the European snow vole in the most southwestern area of its entire distribution range.
\end{abstract}

Keywords: Chionomys nivalis, mtDNA, owl pellet, Sierra Nevada, Sierra Peñalara, Sierra Segura

\section{Introduction}

Assessing small mammal diversity employs widespread standard techniques to gather information for a wide range of studies (Torre et al. 2004). Traditional methods are often biased against animal capturing (Fickel and Hohmann 2006). However, capturing free-ranging animals can be time consuming, difficult, or impractical. In contrast, noninvasive sampling can potentially be a cost-effective and efficient way to monitor wild animals, thereby avoiding unnecessary capture and disturbance (Taberlet and Luikart 1999; Beja-Pereira et al. 2009; Alasaad et al. 2010). The standard first step for species identification methods in many noninvasive studies often involves mtDNA analysis (e.g. Teletchea 2010; Yansen et al. 2010).

Owl pellets, a source for noninvasive sampling, consist of regurgitated, undigested parts of prey, and are thus a valuable source of prey DNA that allows to study the genetics of small mammals predated by owls (Taberlet and Fumagalli 1996). In addition, the poor

Correspondence: S. Alasaad, Estación Biológica de Doñana, Consejo Superior de Investigaciones Científicas (CSIC), Avda. Américo Vespucio s/n 41092 Seville, Spain; Departamento de Biología Experimental, Universidad de Jaén, Campus Las Lagunillas, s/n, E-23071, Jaén, Spain. Tel: + 34954 466700, Fax: + 34954621 125. E-mail: samer@ebd.csic.es 
ability of owls to digest bones renders their pellets even a good source to obtain small mammal skeletons (Andrews 1990). Moreover, because owls occur worldwide and hunt in highly diverse environments, their pellets became the source of choice for a variety of ecological and dietary studies (Guérin 1928; Görner 1979).

The snow vole (Chionomys nivalis, Martins 1842) is a glacial relic that currently has a highly fragmented distribution area spreading from southwestern to southeastern Europe to the Caucasus, Turkey, Israel, Lebanon, Syria, and Iran (Janeau and Aulagnier 1997). This species is usually found in cold rocky habitats above the tree line (Krapp 1982; Amori 1999; Gutiérrez Elorza 2001). Its distribution pattern is thought to be a consequence of microhabitat selection and interspecies competition, rather than of physiological adaptation (Janeau 1980; Janeau and Aulagnier 1997; Nappi 2002).

A recent molecular study across the snow voles' distribution range revealed no clear phylogenetic pattern among the six detected $C$. nivalis mtDNA lineages (Castiglia et al. 2009). Moreover, a mismatch distribution graph was unimodally shaped indicating rapid lineage divergence due to fast population expansion. The study also supports the hypothesis of a European origin of $C$. nivalis and a subsequent eastward dispersion of the species (Castiglia et al. 2009).

There are five main snow vole population nuclei in the Iberian Peninsula (Luque-Larena and Gosálvez 2007). Four of them are located in the northern half of the Peninsula (the Pyrenees mountain range, the Cantabrian mountain range, the Iberian and central systems), whereas the South only harbors the Sierra Nevada mountain range population (Vericad and Meylan 1973; Krapp 1982). The Sierra Nevada National and Natural Parks therefore represent the southwestern edge of the snow vole's world distribution range (Pérez-Aranda et al. 2007). C. nivalis is critically endangered in the southern half of the Iberian Peninsula, and the environmental conditions there are thought to be far from optimal for the species (Pérez-Aranda et al. 2007). Hence, a discovery of any new snow vole population in this area would be of great interest for the conservation of this species in the most southwestern point of its range.

The aim of our study was to discover an undetected European snow vole population from the Sierra Segura mountain range (Southern Spain), based on the morphological and genetic analyses of owl pellet contents.

\section{Materials and methods}

Sierra Segura mountain range

This mountain range is situated in Jaen Province, Southern Spain $\left(37^{\circ} 59^{\prime} 16^{\prime \prime} \mathrm{N}, 2^{\circ} 45^{\prime} 49^{\prime \prime} \mathrm{W} ; 1707 \mathrm{~m}\right.$ above sea level), $102 \mathrm{~km}$ northeast from Sierra Nevada mountain range. The highest peak is $2000 \mathrm{~m}$ above sea level.

The main vegetation is an open forest dominated by European Black Pine Pinus nigra, Savin Juniper Funiperus Sabina, and Common Juniper $\mathcal{F}$. communis (Valle 2003). The surface has a few rocky areas with numerous crevices (López Limia 1987).

\section{Pellet collection, content examination, and morphological examination of bones}

In 2010, we studied the feeding ecology of the long-eared owl Asio otus (Linnaeus 1758) based on pellet remains in the Sierra Segura mountain range. Thirty-eight pellets were collected directly from the owls, roosting places and nests with disposable gloves and stored in plastic bags. After they had been dried, pellets were examined. When bones were found, they were removed from the pellet, cleaned and placed on sterilized drying paper.

On 18, July 2010, we examined an owl pellet of which the basic material was fur, leading us to expect the remains of a prey mammal. The pellet also contained bones, and the skull and jawbones were analyzed using species descriptions by Gosàlbez and Noguera (1987). These species descriptions made us believe that we were dealing with the remains of a snow vole individual.

\section{DNA extraction from bone and tissue material}

Approximately $25 \mathrm{mg}$ of bone from the inferior mandible were used for DNA extraction, following a standard phenol/chloroform procedure (Sambrook et al. 1989). Dry bone material was ground to a fine powder in a small mortar and divided into three equal proportions, aiming to improve DNA extraction success. All DNA extractions (see also below) were carried out in a sterilized laboratory, used exclusively for low DNA concentration samples. Two blanks (reagents only) were included in each extraction to monitor for contamination.

\section{PCR and sequencing of the mtDNA control region}

Polymerase chain reactions (PCRs) to amplify a section of the mitochondrial control region (d-loop) were performed using arvicolid specific primers as described by Alasaad et al. (2011). The $30 \mu \mathrm{l}$ reaction contained $2 \mu \mathrm{l}$ of template DNA (from bone or tissue samples), $0.25 \mu \mathrm{M}$ of Pro + (Haring et al. 2000) and MicoMico primers (Alasaad et al. 2011), $0.12 \mathrm{mM}$ of each dNTP, $3 \mu \mathrm{l}$ of $10 \times$ PCR buffer (Bioline), $1.5 \mathrm{mM} \mathrm{MgCl}_{2}, 0.4 \% \mathrm{BSA}, 1.5 \mu \mathrm{DMSO}$, and $0.2 \mu \mathrm{l}$ (0.2 U/reaction) Taq polymerase (Bioline). Samples were subjected to the following thermal profile for amplification in a PTC0200 thermal cycler (Bio-Rad), 
$4 \mathrm{~min}$ at $94^{\circ} \mathrm{C}$ (initial denaturation), followed by 30 cycles of three steps of $1 \mathrm{~min}$ at $94^{\circ} \mathrm{C}$ (denaturation), $1 \mathrm{~min}$ at $55^{\circ} \mathrm{C}$ (annealing), and $50 \mathrm{~s}$ at $72^{\circ} \mathrm{C}$ (extension). PCRs concluded with a final elongation step of $5 \mathrm{~min}$ at $72^{\circ} \mathrm{C}$. PCR blanks (reagents only) were always included.

Following the PCRs, excess primers and dNTPs were removed using enzymatic reaction of Exonuclease I, Antarctic phosphatase, and Antarctic phosphatase buffer (all New England Biolabs). Sequencing was carried out in both directions using the BigDye ${ }^{\circledR}$ Terminator v1.1 cycle sequencing kit (Applied Biosystems). Labeled fragments were resolved on an automated $\mathrm{A} 3130 \mathrm{Xl}$ genetic analyzer (Applied Biosystems) according to the manufacturer's instructions. Incomplete terminal sequences and PCR primers were excluded from sequence analysis.

\section{Molecular analyses}

Templates were sequenced on both strands, and the complementary reads were used to resolve rare, ambiguous base-calls in Sequencher v.4.9. Sequences were aligned in Seaview v.4.2.11 (Gouy et al. 2010) under ClustalW2 (Larkin et al. 2007) default settings. Nucleotide substitutions, $p$-uncorrected distances $(\%)$, and phylogenetic analyses were performed with PAUP $\star 4 . b .10$ (Swofford 2002) and MrBayes v.3.1.2 (Huelsenbeck and Ronquist 2001). The d-loop GenBank entry of a European snow vole from Austria was used as out-group (AF267284; Haring et al. 2000).

The most appropriate substitution models for the maximum likelihood and Bayesian maximum likelihood analyses were determined by the Akaike information criterion (Posada and Buckley 2004) and the Bayesian information criterion, respectively, as inferred in jModeltest v.0.1.1 (Posada 2008). Trees were constructed using maximum parsimony (MP; heuristic search with TBR branch exchange), maximum likelihood (ML), and Bayesian maximum likelihood (BML) optimality criteria. Clade support in the MP and ML was inferred by 1000 and 100 bootstrap replicates, respectively. MrBayes was used with default priors and Markov chain settings and with random starting trees. The gamma shape parameter and proportion of invariant sites were estimated from the data. Each run consisted of four chains of $10,000,000$ generations, sampled each 10,000 generations for a total of 1000 trees. A plateau was reached after 5000 generations with $10 \%$ (200 trees) of the trees resulting from the analyses discarded as "burn in." Haplotype frequency and a parsimony minimum spanning network of the sequences were analyzed in TCS 1.21 (Clement et al. 2000) following the method of Templeton et al. (1992) in which $\geq 95 \%$ confidence was required for haplotypes to be connected.

\section{Results and discussion}

Following the description of vole teeth morphology reported by Gosàlbez and Noguera (1987), we identified the molars found in the owl pellet as belonging to the European snow vole $C$. nivalis (Figure 1).

Eighteen partial mitochondrial control region sequences of $413 \mathrm{bp}$ in length were amplified (GenBank accession numbers JF410863-JF410880) from which nine haplotypes were identified: Four were from Sierra Nevada (Spain), one from Sierra Segura, another from Sierra Peñalara (Spain), and three from Churwalden (Switzerland). The sequences from Switzerland were incorporated in the alignment to test for the monophyly of the Iberian haplotypes and to assess the genetic divergence between and within both clades. The uncorrected $p$-distances among all in-group haplotypes ranged between $0.2 \%$ and $3.5 \%$, the three haplotypes from Switzerland between $0.5 \%$ and $1.0 \%$, and the five haplotypes belonging to Spanish localities between $0.2 \%$ and $3.5 \%$ (Table I). The best-fitting models for the ML and BML trees were $\mathrm{TVM}+\mathrm{I}((\ln L=765.9197)$ and $\mathrm{HKY}+\mathrm{I}$ ( $(\ln L=769.4707)$, respectively.

The haplotypes fell into four distinct lineages supported by high bootstrap values in all the analyses employed. In our analysis, the clade from Switzerland
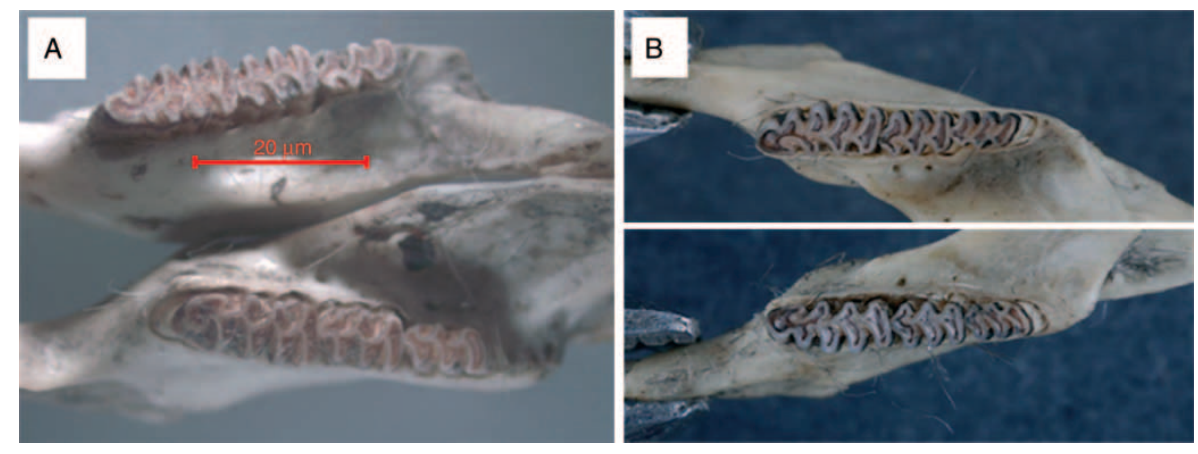

Figure 1. Upper view of the lower mandible of the European snow vole. (A) Chionomys nivalis found in the pellet of a long-eared owl in the Sierra Segura mountain range, Southern Spain. (B) C. nivalis—ref 247/1-Merle-Leignecq (Loire—42) 2009—Guillaume ALLEMAND. 
Table I. Nucleotide substitutions (above diagonal) and p-uncorrected distances (\%, below diagonal) for each pairwise comparison for all Chionomys nivalis haplotypes. AS: the out-group from Austria, SW: Churwalden (Switzerland), SS: Sierra Segura (Spain), SP: Sierra Peñalara (Spain), and SN: Sierra Nevada (Spain).

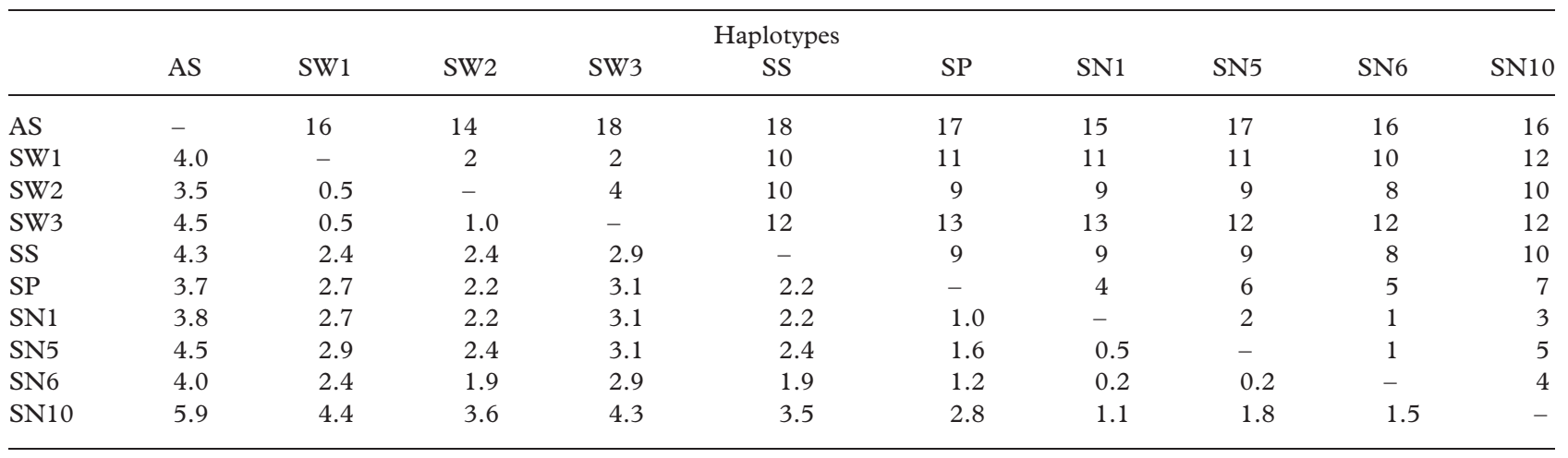

is a sister clade to the Spanish clade. The identified haplotype from Sierra Segura is basal to the other Spanish haplotypes. The haplotype from Sierra Peñalara is basal to the monophyletic clade from Sierra Nevada (Figure 2). All tree-building methods (MP, ML, and BML) recovered the same tree topology, with the exception of some relationships being unresolved among the Sierra Nevada haplotypes. The phylogenetic relationship between the Spanish haplotypes is in congruence from a biogeography viewpoint with the highest genetic divergence associated to geographical distance.

Owls' dispersal is birthplace-dependent (Penteriani and Delgado 2011), and their diet is affected by season, weather, and habitat (Romanowski and Żmihorski 2008). In European Mediterranean areas, rabbits (Oryctolagus cuniculus) represent the main prey for owls (Delibes and Hiraldo 1981; Rogers et al. 1994). Since 1988, a new viral disease, rabbit haemorrhagic disease, has been reported to affect rabbit populations in Mediterranean ecosystems (Villafuente et al. 1995). The diet of many animals, such as the Golden Eagle Aquila chrysaetos (Fernández 1993), the Iberian lynx Lynx pardinus (Ferreras et al. 2011), the fox Vulpes vulpes (Villafuente et al. 1996), and owl species (Martínez and Calvo 2001), is changing due to rabbit population declines. Owls have been reported to prey more frequently on small
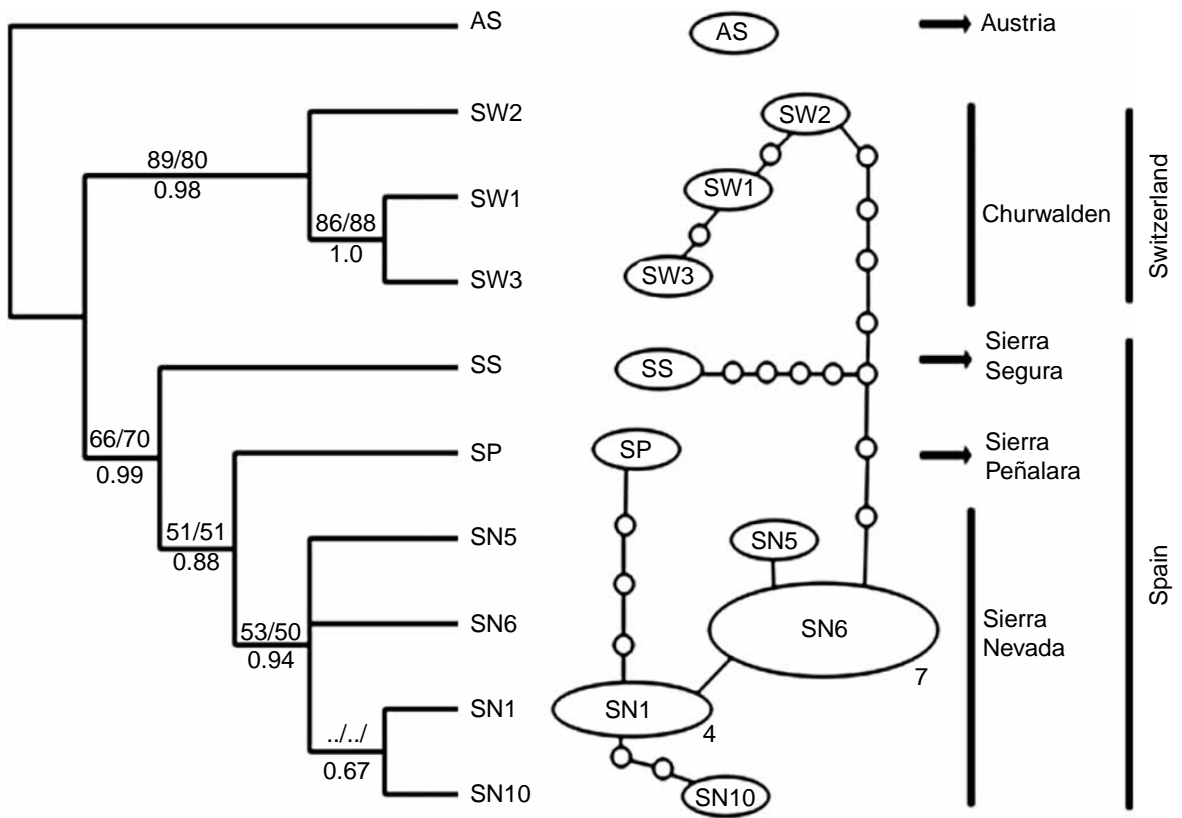

Figure 2. Maximum likelihood strict consensus cladogram (three trees). The values above nodes indicate bootstrap frequencies (\%) from the MP (13 parsimony-informative characters, three best trees: length $=37, \mathrm{CI}=0.81, \mathrm{RI}=0.78$ ) and $\mathrm{ML}$ analyses, respectively. Values under nodes are the posterior probabilities recovered from the Bayesian analysis. The minimum spanning network of all nine haplotypes shows the frequency of each haplotype. The symbols in ovals indicate each haplotype. The size of the circles corresponds to the haplotype frequency. Small circles indicate undetected intermediate haplotype states. The out-group could not be joined to the in-group with greater than $95 \%$ confidence. 
mammals, especially rodents (Donázar et al. 1989; Martínez and Calvo 2001), in areas where rabbits are scarce. Thus, the future use of owl pellets as a noninvasive collectable sample sources for small mammals may lead to the discovery of other $C$. nivalis prey remains or that of other (unknown) rodent populations.

The presence of $C$. nivalis in the Sierra Segura mountain range could be attributed to the abundance of a suitable, open, and cavernous habitat, which permitted the European snow vole to inhabit an altitudinal range (Nadachowski 1991) lower than that in the Sierra Nevada mountain range (2000-3400 m above sea level; Pérez-Aranda et al. 2007). Similarly structured habitats with numerous cavities are also present in other Mediterranean regions allowing $C$. nivalis to inhabit even sea level habitats in Croatia, France, and Spain (Krystufek and Kovacic 1989; Janeau and Aulagnier 1997; Nappi 2002).

This newly discovered and distinct $C$. nivalis haplotype suggests the presence of a so far unknown population in the Sierra Segura mountain range and discards the remote possibility that the vole was caught and transported by the owl from other Spanish localities, particularly if one takes into account that the owls hunting range size is about 250 ha (Martínez et al. 1998). As such, this finding is of great interest for the conservation of the critically endangered vole species in its southwesternmost distributional range (PérezAranda et al. 2007). Additional monitoring of the area with the aim of obtaining a bigger sample size should be performed to infer the distributional range and the size of this putative population. Furthermore, management and conservation programs are required, which might include additional measures such as establishing corridors and buffer zones and/or implementing reintroduction programs after the actual population size and range are established.

\section{Acknowledgements}

The authors wish to express their gratitude to Parque Nacional de Sierra Nevada (Granada, Spain) and Junta de Andalucia for the permission to capture $C$. nivalis. Pedro Pablo Cano Henares (EGMASA) is thanked for fieldwork assistance.

Declaration of interest: This work was supported by the Spanish Ministerio de Ciencia y Tecnología (Spain). This work was supported by the Spanish Ministerio de Ciencia y Tecnología (CGL200907754), and co-funded by the European Regional Development Fund and by the Junta de Andalucía (Program Ayudas a Grupos de Investigación: CVI 220 and RNM118). This paper had been partially funded by a contract between Consejeria de MedioAmbiente (Junta de Andalucia) and Doñana Biological Station (CSIC). The authors report no conflicts of interests.
The authors alone are responsible for doing the research and writing the paper.

\section{References}

Alasaad S, Sánchez A, Marchal JA, Píriz A, Garrido-García JA, Carro F, Romero I, Soriguer RC. 2010. Efficient identification of Microtus cabrerae excrements using noninvasive molecular analysis. Conserv Genet Resour 3:127-129.

Alasaad S, Soriguer RC, Jowers MJ, Marchal JA, Romero I, Sánchez A. 2011. Applicability of mitochondrial DNA for the identification of Arvicolid species from faecal samples: A case study from the threatened Cabrera's vole. Mol Ecol Resour 11: 409-414.

Amori G. 1999. Chionomys nivalis (Martins, 1842). In: Mitchell-Jones AJ, Amori G, Bogdanowicz W, Krystufek B, Reijnders PJH, Spitznberger F, Stubbe M, Thissen JBM, Vohralík V, Zima J, editors. Atlas of European mammals. London: Academic Press. pp 256-257.

Andrews P. 1990. Owls, caves and fossils. Owls, caves and fossils. London: Museum of Natural History Publication. pp 231.

Beja-Pereira A, Oliveira R, Alves PC, Schwartz MK, Luikart G. 2009. Advancing ecological understandings through technological transformations in noninvasive genetics. Mol Ecol Resour 9: 1279-1301.

Castiglia R, Annesi F, Krystufek B, Filippucci MG, Amori G. 2009. The evolutionary history of a mammal species with a highly fragmented range: The phylogeography of the European snow vole. J Zool 279:243-250.

Clement M, Posada D, Crandall KA. 2000. TCS: a computer program to estimate gene genealogies. Mol Ecol 9:1657-1660.

Delibes M, Hiraldo F. 1981. The rabbit as prey in the Iberian Mediterranean ecosystem. In: Myers K, Mclnnes CD, editors. Proceeding Of the World Iagomorph conference (1979). Canada: University Guelph. pp 614-622.

Donázar JA, Hiraldo F, Delibes M, Estrella RR. 1989. Comparative food habits of the Eagle owl Bubo bubo and the Great Horned owl Bubo virginianus in six Palearctic and Nearctic biomes. Ornis Scandinavica 20:298-306.

Fernández C. 1993. Effect of the viral haemorrhagic pneumonia of the wild rabbit on the diet and breeding success of the Golden Eagle Aquila chrysäeto (L.). Revue d'Ecologie (Terre Vie) 48: 323-329.

Ferreras P, Travaini A, Zapata SC, Delibes M. 2011. Short-term responses of mammalian carnivores to a sudden collapse of rabbits in Mediterranean Spain. Basic appl Ecol 12:116-124.

Fickel J, Hohmann U. 2006. A methodological approach for non-invasive sampling for population size estimates in wild boars (Sus scrofa). Eur J Wildl Res 52:28-33.

Görner M. 1979. Zur Verbreitung der Kleinäuger im Südwesten der DDR auf der Grundlage von Gewöllanalysen der Schleiereule (Tyto alba (Scop.)). Zoologisches Jahrbuch für Systematik 106: 429-470.

Gosàlbez IM, Noguera J. 1987. Insectívors i rosegadors de Catalunya: Metodologia d'estudi i catàleg faunístic. Institut d'Estudis Catalans. Institució Catalana d'Història Natural, ISBN: 84-85256-68-9.

Guérin G. 1928. Régime et croissance de l'Effraye commune Tyto alba alba (L.) en Vendée P et Lussaud Frères. France: FontenayLe-Comte.

Gutiérrez Elorza M. 2001. Geomorfología climática, Barcelona: Ed. Omega. p. 664.

Gouy M, Guindon S, Gascuel O. 2010. SeaView version 4. A multiplatform graphical user interface for sequence alignment and phylogenetic tree building. Mol Biol Evol 27:221-224.

Haring E, Herzig-Straschil B, Spitzenberger F. 2000. Phylogenetic analysis of Alpine voles of the Microtus multiplex complex using 
the mitochondrial control region. J Zool Syst Evol Res 38: 231-238.

Huelsenbeck JP, Ronquist FR. 2001. Mrbayes: Bayesian inference of phylogenetic trees. Bioinformatics 17:754-755.

Janeau G. 1980. Répartition écologique des micromammifères dans l'étage alpin de la région de Briançon. Mammalia 44:1-25.

Janeau G, Aulagnier S. 1997. Snow vole- Chionomys nivalis (Martins, 1842). J Mt Ecol 4:1-11.

Krapp F. 1982. Microtus nivalis (Martins, 1842) Schneemaus. In: Niethammer J, Krapp F, editors. Handbuch der Säugetiere Europas, Band 2/1 Rodentia II. Wiesbaden: Aula Verlag. pp 261-283.

Krystufek B, Kovacic D. 1989. Vertical distribution of the snow vole Microtus nivalis (Martins 1842) in Northwestern Yugoslavia. Z Säugetierk 54:135-156.

Larkin MA, Blackshields G, Brown NP, Chenna R, McGettigan PA, McWilliam H. 2007. Clustal W and Clustal X version 2.0. Bioinf App Note 23:2947-2948.

López Limia B. 1987. Geomorfología del karst de Pinar Negro (Sierra de Segura, Jaén) 2., p 1-55, Lapiaz, Monogr.

Luque-Larena JJ, Gosálvez J. 2007. Chionomys nivalis (Martins, 1842). Topillo nival. In: Palomo JL, Gisbert J, Blanco JC, editors. Atlas y Libro Rojo de los mamíferos terrestres de España. Spain: Ministerio de Agricultura, Alimentación y Medio Ambiente. p 410-414.

Martínez DR, Figueroa RA, Ocampo CL. 1998. Food habits and hunting ranges of short-eared owls (Asio flammeus) in agricultural landscapes of southern Chile. J Raptor Res 32: $111-115$.

Martínez JE, Calvo J. 2001. Diet and breeding success of eagle owl in southeastern Spain: effect of rabit haemorrhagic disease. J Raptor Res 35:259-262.

Nadachowski A. 1991. Systematics, geographic variation, and evolution of snow voles (Chionomys) based on dental characters. Acta Theriol 36:1-45.

Nappi A. 2002. Vertical distribution of the snow vole Chionomys nivalis (Martins, 1842) (Rodentia, Arvicolidae) in Italy. Hystrix 13:45-52.

Penteriani V, Delgado MM. 2010. Birthplace-dependent dispersal: Are directions of natal dispersal determined a priori? Ecography. doi: 10.1111/J.1600-0587.2010.6773.x.

Pérez-Aranda D, Carro F, Garrido JA, Cano J, Castillo A, Enrique-Granados J, Suárez F, Soriguer RC. 2007. Nuevos datos sobre la distribución del topillo nival Chionomys nivalis (Martins, 1842) en Sierra Nevada (Andalucía, España). Galemys 19:17-24.

Posada D. 2008. jModelTest: Phylogenetic model averaging. Mol Biol Evol 25:1253-1256.
Posada D, Buckley TR. 2004. Model selection and model averaging in phylogenetics: Advantages of the aic and bayesian approaches over likelihood ratio tests. Syst Biol 53:793-808.

Rogers PM, Arthur CP, Soriguer RC. 1994. The rabbit in continental Europe. In: Thompson HV, King CM, editors. The European rabbit: History and biology of a successful colonizer. Oxford, UK: Oxford University Press. p 22-63.

Romanowski J, Żmihorski M. 2008. Effect of season, weather and habitat on diet variation of a feeding specialist: A case study of the long-eared owl, Asio otus in Central Poland. Folia Zool 57: 411-419.

Sambrook J, Fritsch EF, Maniatis T. 1989. Molecular Cloning: A Laboratory Manual. 2nd ed., Cold Spring Harbor, NY: Cold Spring Harbor Laboratory.

Swofford D. 2002. PAUP ${ }^{\star}$ : Phylogenetic Analysis Using Parsimony ( ${ }^{\star}$ and Other Methods), Version 4. Sinauer Associates, Sunderland, MA.

Taberlet P, Fumagalli L. 1996. Owl pellets as a source of DNA for genetic studies of small mammals. Mol Ecol 5:301-305.

Taberlet P, Luikart G. 1999. Noninvasive genetic sampling and individual identification. Biol J Linn Soc 68:41-55.

Teletchea F. 2010. After 7 years and 1000 citations: Comparative assessment of the DNA barcoding and the DNA taxonomy proposals for taxonomists and non-taxonomists. Mitochondrial DNA 21:206-226.

Templeton AR, Crandall KA, Sing CF. 1992. A cladistic analysis of phenotypic associations with haplotypes inferred from restriction endonuclease mapping and DNA sequence data. III. Cladogram estimation. Genetics 132:619-633.

Torre I, Arrizabalaga A, Flaquer C. 2004. Tree methods for assessing richness and composition of small mammal communities. J Mammal 85:524-530.

Valle F. (ed.) 2003. Mapas de series de vegetación de Andalucía. Madrid: Ed. Rueda-Consejería de Medio Ambiente - 131 .

Vericad JR, Meylan A. 1973. Résultats de quelques piègeages de micromammifères dans le sud-est de l'Espagne. Mammalia 37: 333-341.

Villafuente R, Galvete C, Blanco JC, Lucientes J. 1995. Incidence of viral haemorrhagic disease in wild rabbit populations in Spain. Mammalia 59:651-659.

Villafuente R, Luco DF, Gortázar C, Blanco JC. 1996. Effect on red fox litter size and diet after rabbit haemorrhagic disease in northeastern Spain. J Zool (Lond. 240:764-767.

Yansen Cai, Bisong Yue, Wanxiang Jiang, Shiqi Xie, Jing Li, Ming Zhou. 2010. DNA barcoding on subsets of three families in Aves. Mitochondrial DNA J21:132-137. 